\title{
Assessment of Mechanical, Chemical, and Biological Properties of Ti-Nb-Zr Alloy for Medical Applications
}

\author{
Viktoria Hoppe ${ }^{1, * \mathbb{D}}$, Patrycja Szymczyk-Ziółkowska ${ }^{1}$, Małgorzata Rusińska ${ }^{1}$, Bogdan Dybała ${ }^{1}$, \\ Dominik Poradowski ${ }^{2}$ and Maciej Janeczek ${ }^{2}$ (D)
}

1 Centre for Advanced Manufacturing Technologies-Fraunhofer Project Center, Department of Laser Technologies, Automation and Production Management, Faculty of Mechanical Engineering, Wrocław University of Science and Technology, 50-371 Wrocław, Poland; patrycja.e.szymczyk@pwr.edu.pl (P.S.-Z.); malgorzata.rusinska@pwr.edu.pl (M.R.); bogdan.dybala@pwr.edu.pl (B.D.)

2 Department of Animal Physiology and Biostructure, Division of Anatomy, Faculty of Veterinary Medicine, Wrocław University of Environmental and Life Sciences, 50-375 Wrocław, Poland; dominik.poradowski@upwr.edu.pl (D.P.); maciej.janeczek@upwr.edu.pl (M.J.)

* Correspondence: viktoria.hoppe@pwr.edu.pl

Citation: Hoppe, V.; Szymczyk-

Ziółkowska, P.; Rusińska, M.; Dybała,

B.; Poradowski, D.; Janeczek, M.

Assessment of Mechanical, Chemical, and Biological Properties of Ti-Nb-Zr Alloy for Medical Applications.

Materials 2021, 14, 126. https://doi.org /10.3390/ma14010126

Received: 3 December 2020 Accepted: 25 December 2020 Published: 30 December 2020

Publisher's Note: MDPI stays neutral with regard to jurisdictional clai$\mathrm{ms}$ in published maps and institutional affiliations.

Copyright: (C) 2020 by the authors. Licensee MDPI, Basel, Switzerland. This article is an open access article distributed under the terms and conditions of the Creative Commons Attribution (CC BY) license (https:// creativecommons.org/licenses/by/ $4.0 /)$.

\begin{abstract}
The purpose of this work is to obtain comprehensive reference data of the Ti- $13 \mathrm{Nb}-13 \mathrm{Zr}$ alloy base material: its microstructure, mechanical, and physicochemical properties. In order to obtain extensive information on the tested materials, a number of examination methods were used, including SEM, XRD, and XPS to determine the phases occurring in the material, while mechanical properties were verified with static tensile, compression, and bending tests. Moreover, the alloy's corrosion resistance in Ringer's solution and the cytotoxicity were investigated using the MTT test. Studies have shown that this alloy has the structure $\alpha^{\prime}, \alpha$, and $\beta$ phases, indicating that parts of the $\beta$ phase transformed to $\alpha^{\prime}$, which was confirmed by mechanical properties and the shape of fractures. Due to the good mechanical properties $(\mathrm{E}=84.1 \mathrm{GPa})$, high corrosion resistance, as well as the lack of cytotoxicity on MC3T3 and NHDF cells, this alloy meets the requirements for medical implant materials. Ti-13Nb-13Zr alloy can be successfully used in implants, including bone tissue engineering products and dental applications.
\end{abstract}

Keywords: Ti-13Nb-13Zr; mechanical properties; XPS; corrosion resistance; cytotoxicity

\section{Introduction}

The selection of the orthopaedic material is critical for its function. Material for implants replacing hard tissues should provide excellent mechanical properties, especially the Young's modulus and compressive strength. At the same time, it should be biocompatible, without any cytotoxic effect. The biggest group of materials used for orthopaedic implants are metals: commercially pure titanium, alloys based on titanium or cobalt-chromium, and stainless steel [1]. In long-term research and practice, titanium and its alloys have proven to adapt well to a bone, especially titanium and Ti-6Al-4V alloy, thus becoming the most common in implants [2-4]. Although very popular, these so-called first-generation alloys are not ideal and bring unwanted effects during the post-implantation period. The biggest problem is the stress-shielding effect caused by the high Young's modulus around $110 \mathrm{GPa}$ when compared with the modulus of a natural bone varying between 15 and $30 \mathrm{GPa}[5,6]$. Moreover, the alloying elements ( $\mathrm{Al}, \mathrm{Fe}$, and $\mathrm{V}$ ) have been reported, to some extent, to cause toxic and allergic reactions $[7,8]$.

New material development research processes are constantly searching for new and better materials for implant manufacturing. The biggest challenge in developing metallic implants for bones is to find a material with a modulus of elasticity similar to that of the neighbouring bone tissue and at the same time biocompatible in long-term exposition. 
New trends in the developing titanium alloys for applications in biomedical engineering lead to alloys consisting of nontoxic and non-allergic alloying elements while maintaining excellent mechanical properties (particularly Young's modulus to strength ratio) $[9,10]$, [11]. The elastic modulus of recently developed alloys ranges from 55 to $85 \mathrm{GPa}$, which is much less than for commonly used alloys [12]. These so-called secondgeneration titanium alloys have higher beta phase content in the microstructure and more biocompatible alloying elements. The alloying elements from the first-generation alloys are replaced by others: $\mathrm{V}$ is replaced by $\mathrm{Nb}, \mathrm{Fe}$, and $\mathrm{Mo}$, while $\mathrm{Al}$ is replaced by $\mathrm{Ta}, \mathrm{Hf}$, and $\mathrm{Zr}$. New $\beta$-titanium alloys with $\mathrm{Nb}, \mathrm{Ta}$, and $\mathrm{Zr}$ as the main alloying elements constitute an emerging group of alloys for biomedical applications as they offer lower values of Young's modulus ( $\approx 60 \mathrm{GPa}$ ), which is now more comparable to the mechanical properties of bones and higher biocompatibility than generally used Ti-6Al-4V and CP Ti [13]. It is assumed that elements such as $\mathrm{Ta}, \mathrm{Nb}, \mathrm{Zr}$, and $\mathrm{Hf}$ may have favourable bio-neutrality generally attributed to titanium $[14,15]$.

Literature reports indicate that $\beta$-titanium alloys have better strength and lower modulus of elasticity than $\alpha$ or $\alpha+\beta$ Ti alloys. For this reason, in recent years, more and more attention has been devoted to the development of a new generation of $\beta$ Ti alloys consisting only of biocompatible components [16-18]. The Ti-Nb-Zr system was developed based on excellent properties of the two-component Ti-Zr system introduced in the early 1990s $[11,19,20]$. The undoubted advantage of alloys based on the Ti- $\mathrm{Nb}-\mathrm{Zr}$ system is their high corrosion resistance because the passive layers forming these elements are permanent, their adhesion to the metallic substrate is good, and the tissue dissolution rate in the surrounding physiological fluids is low $[11,17,21]$. The Ti-13Nb-13Zr alloy is passive in simulated physiological conditions, such as Ringer's [22-24] and Hank's [25] solutions, artificial saliva solution and phosphate-buffered saline (PBS) [26]. However, it shows activity in hydrochloric acid solutions [27]. Another research indicates that alloys based on the $\mathrm{Ti}-\mathrm{Nb}-\mathrm{Zr}$ system are potentially more resistant to environmental factors in orthopaedic applications than dental [28].

From the practical side, the main difference between the first and second generation of titanium alloys is that the clinical community has much more experience and long-term evaluation data showing titanium and its traditional alloys as a safe and functional material for medical applications, and therefore, it is more often applied. In addition, R\&D costs and expenses related to regulatory approval of the second-generation titanium alloys and its modifications are assumed to be more favourable than for the group consisting of Ta, $\mathrm{Nb}, \mathrm{Zr}$, and $\mathrm{Hf}$, affecting the industry development and the clinical introduction of the new implant materials [29]. Nevertheless, the research for better orthopaedic implant materials continues and our input - the assessment of mechanical, chemical, and biological properties of $\mathrm{Ti}-\mathrm{Nb}-\mathrm{Zr}$ alloy-is presented below.

\section{Materials and Methods}

For the experiments, samples of the Ti-13Nb-13Zr ASTM F-1713:2008 alloy (Shaanxi Yuzhong Industry Development Co., Baoji, China) were delivered in the form of a cylinder $\varnothing=40 \mathrm{~mm}$ and $\mathrm{L}=200 \mathrm{~mm}$. This material was used to prepare standardised samples for mechanical testing in order to determine tensile, compressive, and flexural strength. To obtain the desired geometries, the Wire Electrical Discharge Machining method was used. Then, prefabricated rods and plates with reduced size were prepared and adjusted to the required geometries using a CNC lathe ST-10 (Haas Automation Inc., Oxnard, CA, USA) and CNC milling machine VF-1 (Haas Automation Inc.). For full characterisation of the investigated alloy-to confirm possibilities of its application as an implantation material - the microstructure, electrochemical, and biological properties were investigated using samples in the form of pellets with dimensions Ø14 $\mathrm{mm} \times 2 \mathrm{~mm}$. 


\subsection{Material Properties Analyses}

Macroscopic images were taken using a VHX digital microscope (Keyence, Osaka, Japan). The microstructure was investigated with a Scanning Electron Microscope EVO MA 25 (Zeiss, Oberkochen, Germany). The samples in the form of plates were prepared for SEM analysis by grinding on abrasive from \#200 to \#2000 and polishing using colloidal $\mathrm{SiO}_{2}$ to obtain a mirror surface and then etched with Kroll reagent $(92 \mathrm{~mL}$ distilled water $+6 \mathrm{~mL}$ nitric acid $+2 \mathrm{~mL}$ hydrofluoric acid). Phase analysis was performed using an X-ray powder diffractometer MiniFlex 600 (Rigaku, Tokyo, Japan) and Smart Lab Studio II software (Rigaku, Tokyo, Japan). XRD was conducted using $\mathrm{CuK} \alpha$ radiation and a scanning speed of $2^{\circ} / \mathrm{min}$ from $30^{\circ}$ to $90^{\circ}$. Square surfaces $(20 \mathrm{~mm} \times 20 \mathrm{~mm})$ were polished using \#2000 abrasive and colloidal $\mathrm{SiO}_{2}$ with polishing cloth to ensure that the diffractometry was performed in the interior structure.

\subsection{X-ray Photoelectron Spectroscopy}

X-ray photoelectron spectroscopy (XPS) spectra were obtained with a Kratos Axis Supra spectrometer (Kratos-Shimadzu, Tokyo, Japan) with a monochromatic $\mathrm{Al} \mathrm{K \alpha}$ radiation source $(1486.7 \mathrm{eV})$. The instrument was calibrated for $\mathrm{BE}=84.0 \mathrm{eV} \pm 0.1 \mathrm{eV}$ for the $4 \mathrm{f} 7 / 2$ line of metallic gold. The spectrometer dispersion was adjusted to give $\mathrm{BE}=932.62 \mathrm{eV}$ for the $\mathrm{Cu} 2 \mathrm{p} 3 / 2$ line of metallic copper. The energy resolution was examined on a metallic silver sample. Survey(wide) spectra were gathered with a quality corresponding to the full width at half maximum (FWHM) parameter for $\mathrm{Ag} 3 \mathrm{~d}$ line equal to $0.71 \mathrm{eV}$ at energy step size $0.5 \mathrm{eV}$. For high-resolution spectra, the FWHM parameter for the $\mathrm{Ag} 3 \mathrm{~d}$ line was equal to $0.58 \mathrm{eV}$ at a step size of $0.1 \mathrm{eV}$. The peaks fitting was performed using CasaXPS software version 2.3.18 (Casa, Osaka, Japan) on a Shirley background.

\subsection{Mechanical Properties Analyses}

The strength tests to determine the mechanical properties of the Ti-13Nb-13Zr alloy were executed on the universal Instron 3385 (Instron, Norwood, MA, USA) testing machine with a maximum load of $150 \mathrm{kN}$. Detailed data on standards, sample dimensions, and mechanical test parameters are presented in Table 1. A static tensile test was performed based on the ASTM E8/E8M-16a standard [30]. The test was performed for traverse constant speed of $2 \mathrm{~mm} / \mathrm{min}$ using a video extensometer. The end of the test occurred when the sample was broken. The test was carried out for 10 samples. A static compression test was carried out based on ASTM E9-09 standard [31]. The test was performed for a traverse constant speed of $1 \mathrm{~mm} / \mathrm{min}$. The end of the test occurred when the sample was broken. The test was carried out for 10 samples. A static bending test was carried out based on the ASTM E290-14 standard [32]. The distance between the lower rollers was chosen according to the standard, and it was set at $19 \mathrm{~mm}$. Samples were bent at a constant speed of $1 \mathrm{~mm} / \mathrm{min}$. The criterion for the end of the test was a load decrease of about $10 \%$ after the sample break.

\subsection{Electrochemical Properties Analyses}

Electrochemical measurements were executed on specimens with the working area of $0.75 \mathrm{~cm}^{2}$, in a Ringer's solution $\left(8.6 \mathrm{~g} / \mathrm{dm}^{3} \mathrm{NaCl}, 0.3 \mathrm{~g} / \mathrm{dm}^{3} \mathrm{KCl}, 0.243 \mathrm{~g} / \mathrm{dm}^{3} \mathrm{CaCl}_{2}\right)$, at room temperature $\left(25^{\circ} \mathrm{C}\right)$, using an Atlas Sollich 1131 electrochemical potentiostat (Atlas Sollich, Rębiechowo, Poland). The working electrode was grinded with SiC \#2000 abrasive paper before each experiment. Corrosion resistance measurements were executed by potentiodynamic polarisation using a platinum electrode as a counter electrode (CE), calomel electrode as a reference (SCE) and sample as a working electrode (WE). Before each experiment, the Open Circuit Potential (OCP) was recorded after $120 \mathrm{~min}$ of resting in the electrolyte when the potential changes were under $1 \mathrm{mV} / \mathrm{min}$. Tafel curves were recorded 
by changing the electrode potential from -0.3 to $+1.5 \mathrm{~V}$ versus the OCP potential with a rate of $1 \mathrm{mV} / \mathrm{s}$. The Stern-Geary Equation (1) was used to calculate the polarisation resistance:

$$
R_{p}=\frac{\beta_{a} \times \beta_{c}}{2.303 \times\left(\beta_{a}+\beta_{c}\right) \times i_{c o r r}}
$$

where: $\beta_{a}$ is the anodic Tafel slope, $\beta_{c}$ is the cathodic Tafel slope, and $i_{c o r r}$ is the corrosion current density. Tafel curves were recorded for 5 measurements, the results were averaged, and the deviation was reported.

Table 1. Parameters of mechanical tests of Ti13Nb13Zr alloy.

\begin{tabular}{|c|c|c|c|c|c|}
\hline Type of Test & $\begin{array}{l}\text { Measured } \\
\text { Parameters }\end{array}$ & Standard & Dimensions & Traverse Speed & $\begin{array}{l}\text { Number of } \\
\text { Specimens }\end{array}$ \\
\hline Static tensile test & $\begin{array}{l}\text { UTS } \\
\text { YS } \\
\text { A } \\
\text { E }\end{array}$ & $\begin{array}{c}\text { ASTM } \\
\text { E8/E8M-16a }\end{array}$ & $\begin{array}{c}\mathrm{G}=20.0 \pm 0.1 \mathrm{~mm} \\
\mathrm{D}=4.0 \pm 0.1 \mathrm{~mm} \\
\mathrm{R}=4 \mathrm{~mm} \\
\mathrm{~A}_{\min }=24 \mathrm{~mm}\end{array}$ & $2 \mathrm{~mm} / \mathrm{min}$ & 10 \\
\hline Static compression test & $\begin{array}{l}\mathrm{CS} \\
\mathrm{YS}_{\mathrm{c}}\end{array}$ & $\begin{array}{l}\text { ASTM } \\
\text { E9-09 }\end{array}$ & $\begin{array}{c}\mathrm{D}=6.5 \pm 0.1 \mathrm{~mm} \\
\mathrm{~L}=12.5 \pm 0.5 \mathrm{~mm} \\
\mathrm{~L} / \mathrm{D}=2\end{array}$ & $1 \mathrm{~mm} / \mathrm{min}$ & 10 \\
\hline Static bending test & FS & ASTM E290-14 & $\begin{array}{c}\mathrm{W}=20.0 \pm 0.2 \mathrm{~mm} \\
\mathrm{~T}=3.0 \pm 0.1 \mathrm{~mm} \\
\mathrm{~L}=75.0 \pm 0.2 \mathrm{~mm}\end{array}$ & $1 \mathrm{~mm} / \mathrm{min}$ & 10 \\
\hline
\end{tabular}

\subsection{Biological Properties Analyses}

Cytotoxicity studies were performed according to the MTT protocol based on EN ISO 10993-5:2012 [33] and EN ISO 10993-5:2009 standard [34]. The research was carried out on the normal human dermal fibroplast (NHDF) cell line (American Type Culture Collection, Manassas, VA, USA) and the MC3T3-E1 mouse preosteoblast line (American Type Culture Collection). Cells of the tested lines were applied to Eppendorf 96-well culture plates. Then, $100 \mu \mathrm{L}$ of cells suspended in medium at a density of $1 \times 10^{5} / \mathrm{mL}$ (corresponding to $1 \times 10^{4} /$ well) were added to each well. Extracts from the tested samples were prepared in the proportion: $0.2 \mathrm{~g}$ of sample per $1 \mathrm{~cm}^{3}$ of culture medium DMEM (Dulbecco's Modified Eagle Medium) supplemented with fetal bovine serum (FBS) for $24 \mathrm{~h}$ in a controlled environment $\left(37^{\circ} \mathrm{C}, 5 \% \mathrm{CO}_{2}\right.$, full humidity). The concentrations tested were $100 \%, 50 \%, 25 \%$, and $12.5 \%$ of the initial concentration of the extract. In this study, two controls were used: positive (mitomycin C at concentration of $2 \mu \mathrm{g} / \mathrm{mL}$ ) and negative (untreated cells). The blank was a culture medium with the composition as mentioned above. Then, the obtained extracts were introduced into the cell culture described above and incubated for $72 \mathrm{~h}$ in $5 \% \mathrm{CO}_{2}$ at $37^{\circ} \mathrm{C}$. For better clarity of results, 10 independent replicates, for four concentrations of the test sample extract in the medium, were conducted. After the incubation, $100 \mu \mathrm{L}$ of isopropyl alcohol was added to the wells to dissolve the violet formazan crystals, which appear in metabolically active cells. The absorbance of the formazan solution, after gentle mixing, was read at wavelength $\lambda=570 \mathrm{~nm}$ and reference wavelength $\lambda=720 \mathrm{~nm}$ in Multiscan Go spectrophotometer (ThermoFisher, Waltham, MA, USA). The percentage of live cells was calculated by comparing the absorbance value of the test samples with the value of the control (untreated cells). Control absorbance was assumed as $100 \%$.

\section{Results}

\subsection{Material Properties Analyses}

A typical annealed Ti-13Nb-13Zr SEM microstructure is shown in Figure 1. It contains a finely dispersed acicular $\alpha$ martensite in $\beta$ matrix; very soft prior $\beta$ grain boundaries are also visible. In morphological terms, the $\alpha$-phase is enriched in $\mathrm{Zr}$ (neutral element), and 
the $\beta$-matrix is enriched in $\mathrm{Nb}$ ( $\beta$-stabilised element). The microscopic image indicates that the structure was not aged.

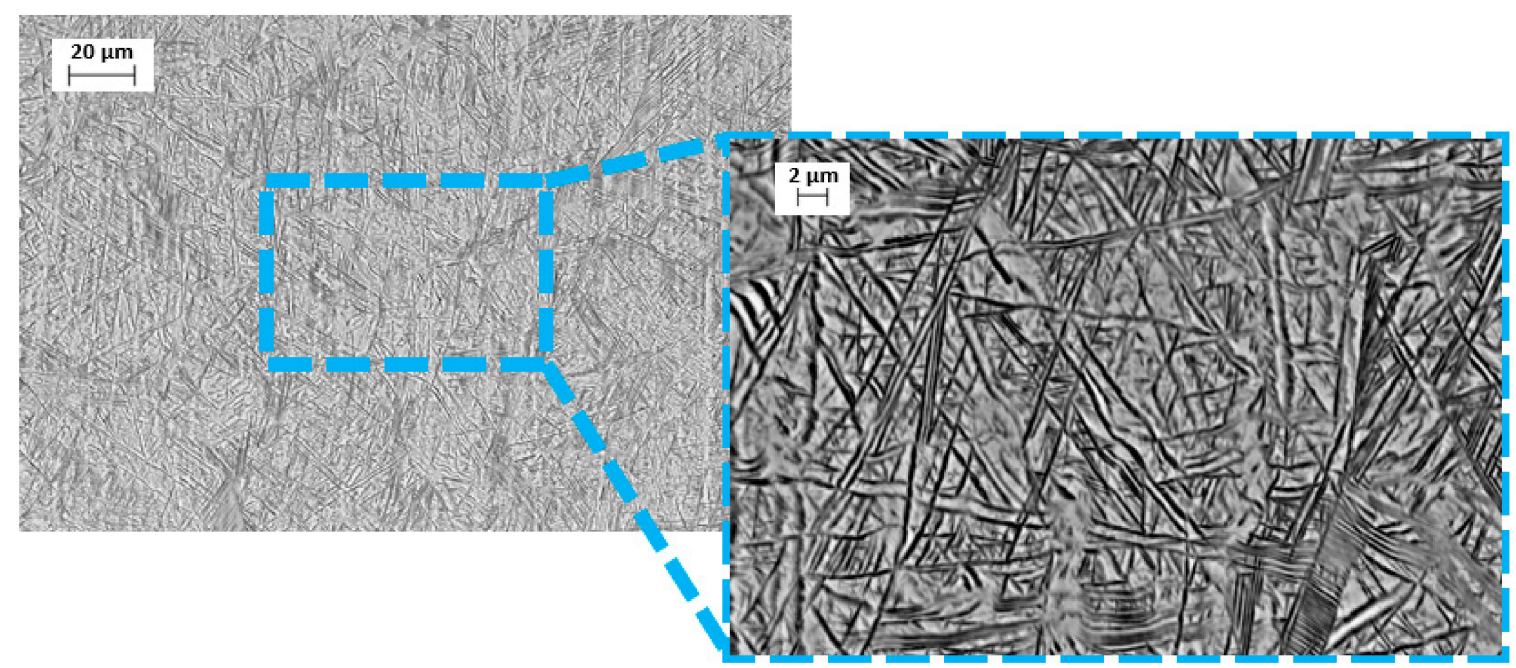

Figure 1. Microscopic image of Ti-13Nb-13Zr alloy microstructure, SEM, BSE.

The presence of two phases was verified through X-ray diffraction (XRD) investigations. Figure 2 summarises typical X-ray diffraction pattern for Ti-13Nb-13Zr. All the major peaks were indexed as $\alpha$-Ti and $\beta$-Ti. Bragg's peak indexation denotes the presence of $\alpha$-Ti (PDF ICDD 00-044-1294) and $\beta$-Ti (PDF ICDD 01-089-3726) phases.

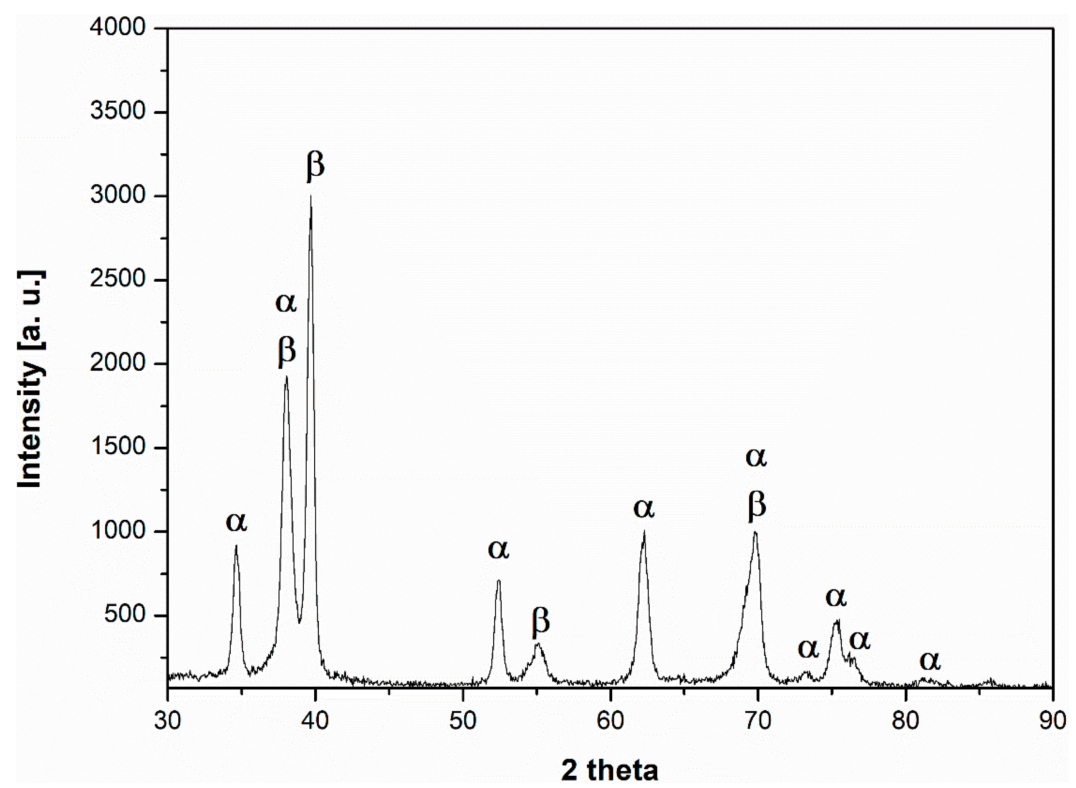

Figure 2. X-ray diffraction pattern with marked $\alpha$ and $\beta$ phase reflections.

The chemical composition specified by the Ti-13Nb-13Zr manufacturer is presented in Table 2. These results are compared with the requirements of the ASTM F1713 standard [35].

It was found that the chemical composition meets these requirements, and the contents of individual elements are within the ranges required.

\subsection{X-ray Photoelectron Spectroscopy}

A widescan XPS survey of Ti-13Nb-13Zr titanium alloy showed major peaks domination at $\mathrm{Ti}, \mathrm{O}$, and $\mathrm{C}$, additionally $\mathrm{Zr}$ and $\mathrm{Nb}$, and moreover, there are detected peaks from contaminants such as $\mathrm{N}$ and $\mathrm{F}$ [36]. In the high-energy part of the XPS spectra, there are wide MNN Auger bands of $\mathrm{Zr}$ and $\mathrm{Nb}(\approx 1105 \mathrm{eV}$ and $\approx 1085 \mathrm{eV}$, respectively), LMM Ti 
Auger bands $(\approx 1065 \mathrm{eV}), \mathrm{KVV}$ Auger bands of $\mathrm{C}, \mathrm{N}, \mathrm{O}$ and $\mathrm{F}(\approx 990 \mathrm{eV}, \approx 1105 \mathrm{eV}, \approx 990 \mathrm{eV}$, $\approx 858 \mathrm{eV}$ respectively) (Figure 3). Moreover, on the widescan, a dominated doublet peak is visible at $\approx 460$ and $\approx 465 \mathrm{eV}$ for $\mathrm{Ti}$, which can be assigned to Ti oxide [37,38]. The presence of small amounts of nitrides and carbides is an effect of machining of titanium surfaces in the presence of air and organic lubricants [39].

Table 2. Chemical composition of Ti-13Nb-13Zr alloy in (wt\%).

\begin{tabular}{cccccccccc}
\hline Elements & Ti & Nb & Zr & O (max) & Fe (max) & H (max) & C (max) & N (max) \\
\hline $\begin{array}{c}\text { ASTM } \\
\text { F1713 }\end{array}$ & $77.46-74.46$ & $12.50-14.00 \pm 0.30$ & $12.50-14.00 \pm 0.40$ & $0.15 \pm 0.02$ & $0.25 \pm 0.10$ & $0.012 \pm 0.0020$ & $0.08 \pm 0.02$ & $0.05 \pm 0.02$ \\
\hline $\begin{array}{c}\text { Producer } \\
\text { report }\end{array}$ & 74.71 & 12.8 & 12.2 & 0.094 & 0.1 & 0.005 \\
\hline
\end{tabular}

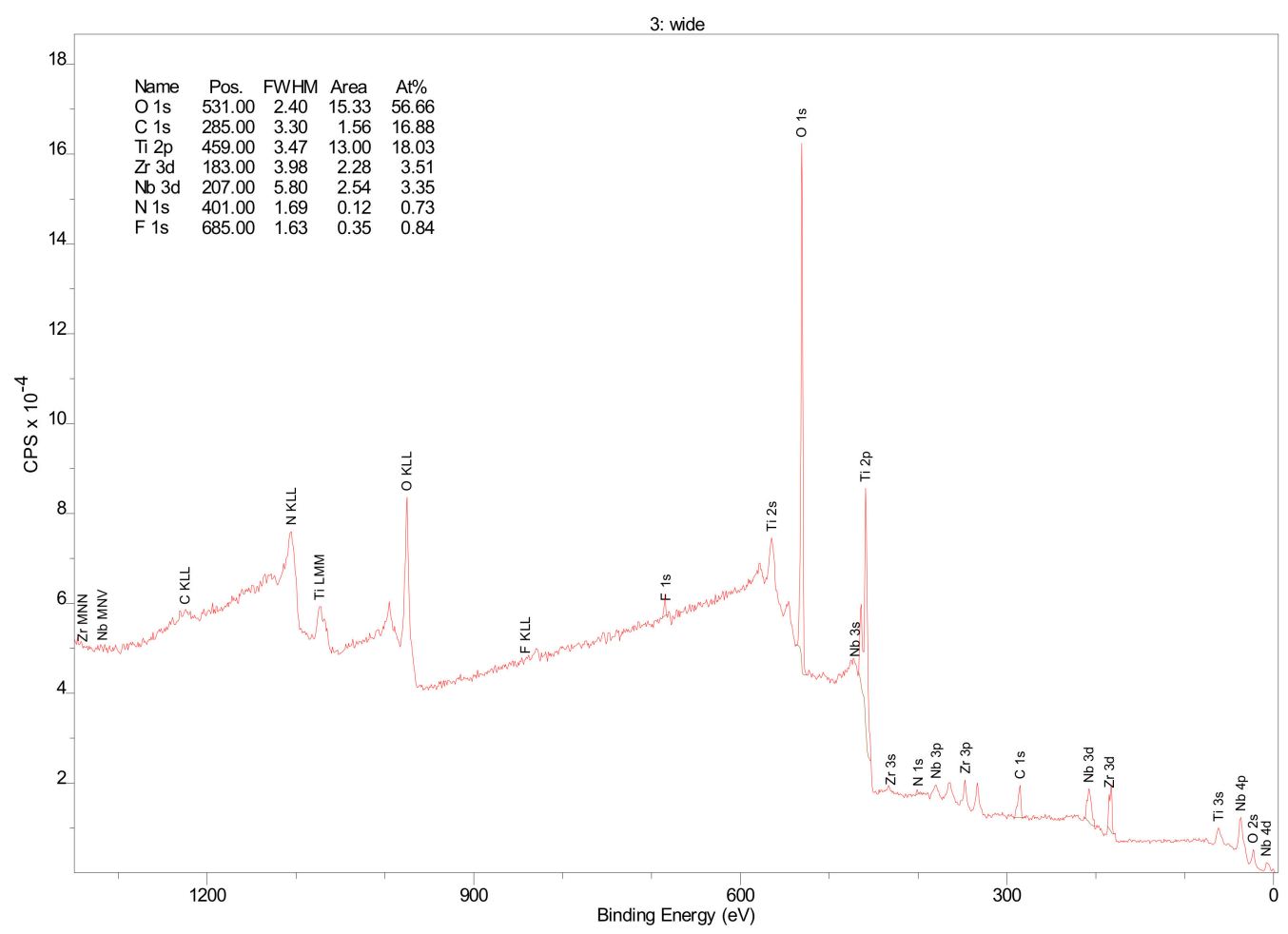

Figure 3. XPS widescan spectra of Ti-13Nb-13Zr titanium alloy sample after etching using $\mathrm{Ar}^{+} 3 \mathrm{~min}$, $3 \mathrm{kV}, 20 \mu \mathrm{A} / \mathrm{cm}^{2}$.

Relative atom concentrations and binding energies of all elements are summarised in Table 3.

Table 3. Binding energies of elements and their relative atom concentration from XPS widescan spectra.

\begin{tabular}{ccccc}
\hline Name & Position (eV) & FWHM & Raw Area & \%At Conc \\
\hline $\mathrm{O} 1 \mathrm{~s}$ & 531.00 & 2.40 & 318459 & 56.66 \\
\hline $\mathrm{C} \mathrm{1s}$ & 285.00 & 3.30 & 26929.9 & 16.88 \\
\hline $\mathrm{Ti} 2 \mathrm{p}$ & 459.00 & 3.47 & 256238 & 18.03 \\
\hline $\mathrm{Zr} \mathrm{3d}$ & 183.00 & 3.98 & 36626.4 & 3.51 \\
\hline $\mathrm{Nb} 3 \mathrm{~d}$ & 207.00 & 5.80 & 41470.6 & 3.35 \\
\hline $\mathrm{N} \mathrm{1s}$ & 401.00 & 1.69 & 2298.6 & 0.73 \\
\hline
\end{tabular}

Deconvoluted XPS data revealed the presence of $\mathrm{Ti}, \mathrm{Nb}$, and $\mathrm{Zr}$ but also $\mathrm{O}$, as expected, as that element is commonly adsorbed on Ti surfaces. The spectra are dominated by $\mathrm{Ti}$ 
and $\mathrm{O}$ due to the naturally formed $\mathrm{TiO}_{2}$ layer. Deconvolution of the $\mathrm{O}$ spectra (Figure 4) showed the presence of hydroxides, which frequently shows spectral components for $531 \mathrm{eV}$, which may be assigned to $\mathrm{OH}$. The Ti $2 \mathrm{p}$ spectrum obtained from the Ti gives 4 doublets, corresponding to the valences $\mathrm{Ti}^{0}$ (metallic state), $\mathrm{Ti}^{2+}(\mathrm{TiO}), \mathrm{Ti}^{3+}\left(\mathrm{Ti}_{2} \mathrm{O}_{3}\right)$, and $\mathrm{Ti}^{4+}\left(\mathrm{TiO}_{2}\right)[40]$, as shown in Figure 5.



Figure 4. Deconvolution XPS spectra of oxygen.

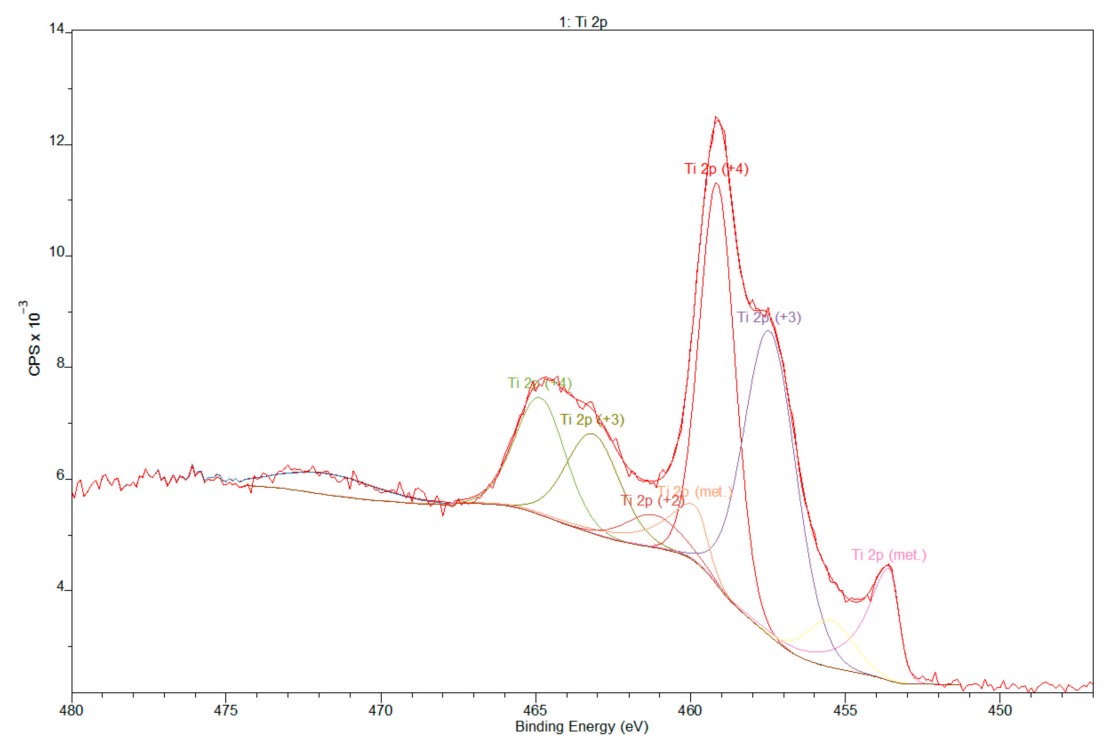

Figure 5. Deconvolution XPS spectra of titanium.

Deconvolution of spectra of niobium showed the presence of peaks that corresponds to valences $\mathrm{Nb}^{0}$ (metallic state), $\mathrm{Nb}^{4+}$, and $\mathrm{Nb}^{5+}\left(\mathrm{Nb}_{2} \mathrm{O}_{5}\right)$ [41] (Figure 6). $\mathrm{Zr} 3 \mathrm{~d}$ spectra obtained from $\mathrm{Zr}$ showed peaks that correspond to the valences $\mathrm{Zr}^{0}$ (metallic state) and $\mathrm{Zr}^{4+}\left(\mathrm{Zr}_{2} \mathrm{O}\right)$ [42] (Figure 7).

\subsection{Mechanical Properties Analyses}

The results obtained for the mechanical properties present curves with a typical shape, which is characteristic for materials with proof stress (stress is taken at which $0.2 \%$ plastic deformation occurs). During static tensile strength, the parameters included in the ASTM F1713-08 standard [35] were determined. The average UTS (Ultimate Tensile Strength) for the tested Ti-13Nb-13Zr alloy samples was $733.9 \pm 7.5 \mathrm{MPa}, \mathrm{YS} 0.2 \%$ 
(Yield Strength, proportional elastic limit with an elongation of $0.2 \%$ ) was $555.6 \pm 17.3 \mathrm{MPa}$, and $\mathrm{A}$ (Elongation) was $19.6 \pm 1.6 \%$. One of the most important parameters from the point of view of biomedical engineering was also determined-the value of Young's modulus was $84.1 \pm 1.8 \mathrm{GPa}$. Moreover, during the static compression test, parameters such as CS (compressive strength) and YSc (compression yield strength) were determined. The following results were obtained: CS was $1378.9 \pm 55.8 \mathrm{MPa}$ and YSc was $757.3 \pm 34.9 \mathrm{MPa}$, respectively. During the three-point bending test, the FS (flexural strength) was determined and was $1708.2 \pm 43.9 \mathrm{MPa}$. Table 4 presents gathered results compared with ASTM F1713 and supplier certificate.

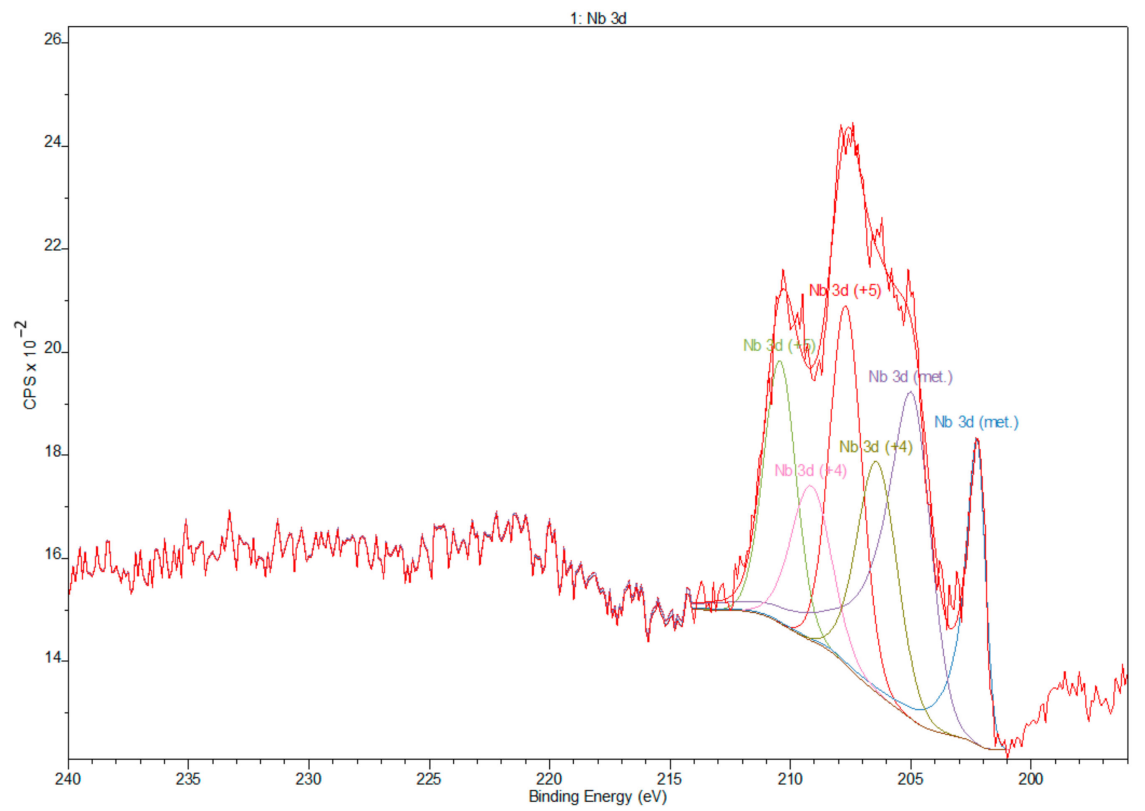

Figure 6. Deconvolution XPS spectra of niobium.



Figure 7. Deconvolution XPS spectra of zirconium.

The obtained results are similar to those provided by the manufacturer. The deviations may result from the research method used. Additionally, the supplier's certificate did not provide values that correspond to the results obtained during static compression and 
bending tests. It is worth mentioning that the difference concerning the requirements of the ASTM F1713 standard and results from this research appeared due to the treatment (annealing) applied by the supplier other than that described in the standard.

Table 4. Mechanical properties of Ti-13Nb-13Zr alloy.

\begin{tabular}{|c|c|c|c|c|c|c|c|}
\hline & $\begin{array}{l}\text { UTS } \\
\text { (MPa) } \\
\text { (min) }\end{array}$ & $\begin{array}{l}\text { YS } \\
\text { (MPa) } \\
\text { (min) }\end{array}$ & $\begin{array}{l}\text { A (\%) } \\
(\mathrm{min})\end{array}$ & $\begin{array}{c}E \\
(\mathrm{GPa})\end{array}$ & $\begin{array}{c}\mathrm{CS} \\
(\mathrm{MPa})\end{array}$ & $\begin{array}{l}\mathrm{YS}_{\mathrm{c}} \\
(\mathrm{MPa})\end{array}$ & $\begin{array}{c}\text { FS } \\
(\mathrm{MPa})\end{array}$ \\
\hline $\begin{array}{l}\text { ASTM F1713 } \\
\text { (unannealed) }\end{array}$ & 550 & 345 & 15 & $64-77$ & n.d. & n.d. & n.d. \\
\hline $\begin{array}{c}\text { Supplier } \\
\text { Certificate } \\
\left(\text { annealed }{ }^{*}\right)\end{array}$ & 690 & 446 & 25 & n.d. & n.d. & n.d. & n.d. \\
\hline This research & $733.9 \pm 7.5$ & $555.6 \pm 17.3$ & $19.6 \pm 1.6$ & $84.1 \pm 1.8$ & $1378.9 \pm 55.8$ & $757.3 \pm 34.9$ & $1708.2 \pm 43.9$ \\
\hline
\end{tabular}

The stress-strain curves of the investigated alloy from tensile and compression tests are presented in Figures 8 and 9, respectively. When analysing these figures, it can be seen that the curves take the typical shape that is characteristic of materials that do not exhibit a clear yield point. The obtained curves for all static tensile test samples were similar to the linear characteristics - the curves were within the range of the Hooke's law, which made determining Young's modulus possible.



Figure 8. Experimental stress-strain curves obtained from the static tensile test for Ti- $13 \mathrm{Nb}-13 \mathrm{Zr}$ alloy.

Results of three-point bending and curves obtained in this test are found on the flexural strength versus deflection curve (Figure 10). The figure below shows the area of elastic deformation up to $1200 \mathrm{MPa}$, plastic deformation 1600-1800 MPa, and cracks marked by a clear decrease in strength.

Samples that were subjected to mechanical properties tests were analysed using fractography methods. Samples after static tensile test were characterised by distributive beam fracture. It is formed by detaching the upper and lower parts of the sample from each other, and its orientation is perpendicular to the direction of the formation of the largest tensile stress. Due to the fact that before the sample breaks, plastic deformation also occurs, this fracture is not completely brittle, and a neck is formed during stretching. A brittle fracture can be observed in the central part of the sample (Figure 11). It is characterised by a shiny, irregular surface. Around the brittle fracture, a slip fracture may be seen with a matte, smooth surface. 


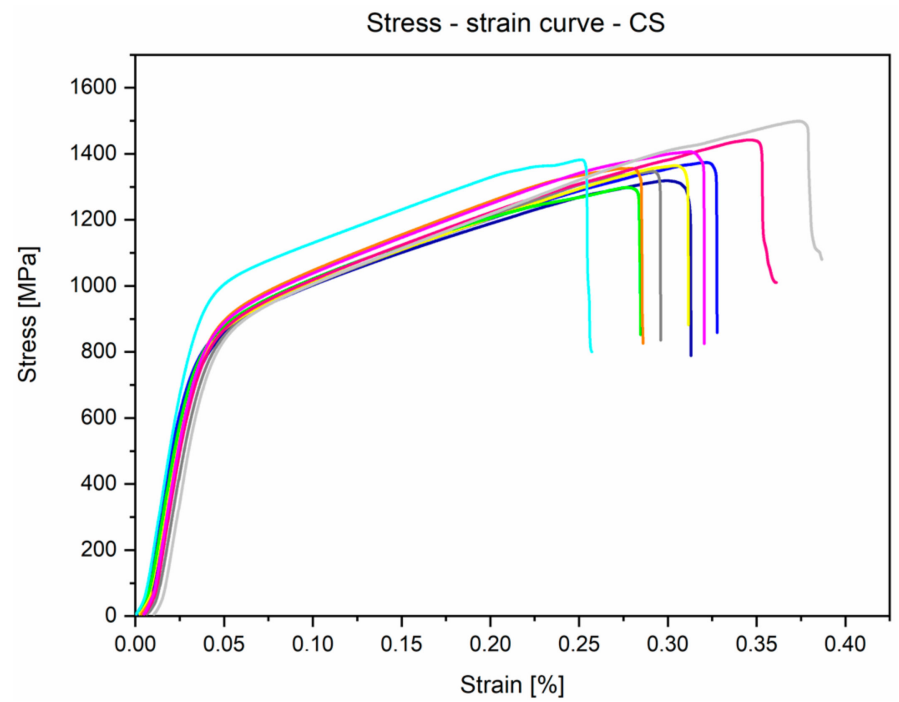

Figure 9. Experimental stress-strain curves obtained from the static compression test for Ti-13Nb$13 Z$ r alloy samples.

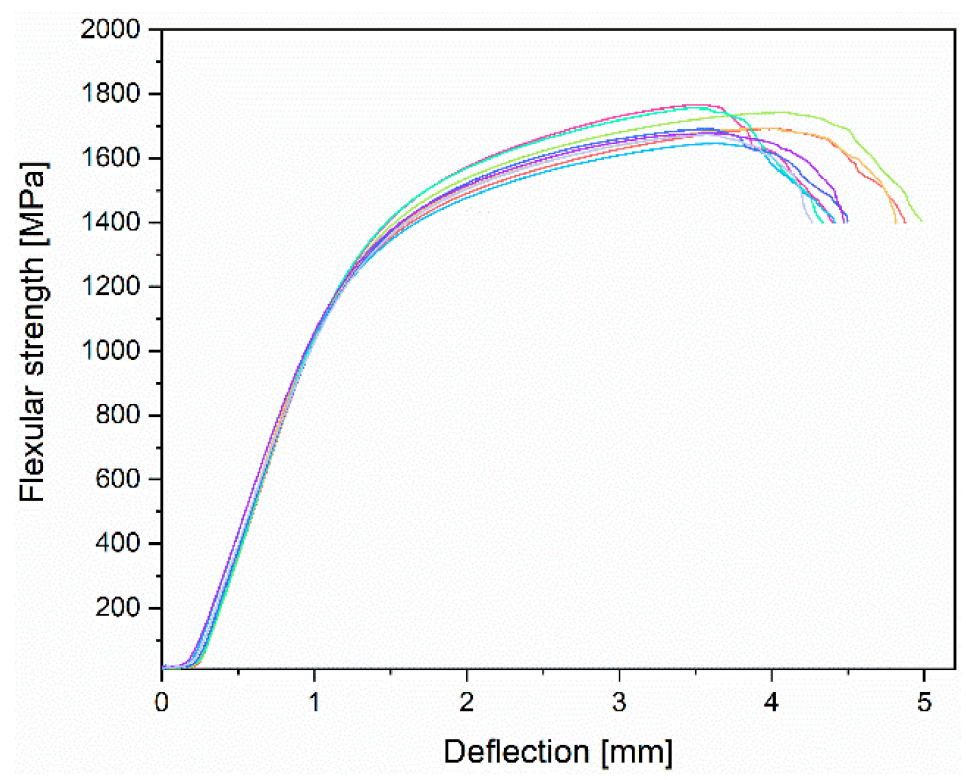

Figure 10. Experimental strength-deflection curves obtained from the three-point bending test for Ti-13Nb-13Zr alloy samples.

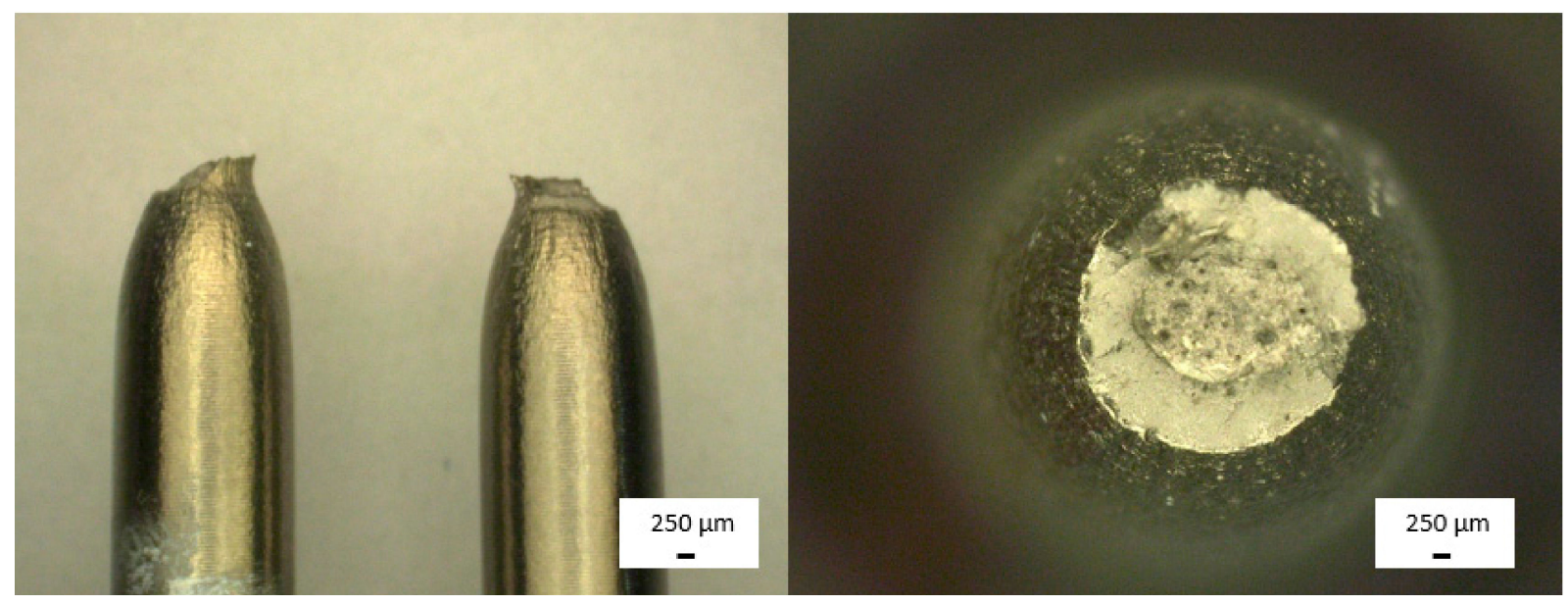

Figure 11. Light microscopy images of Ti-13Nb-13Zr samples after static tensile test. 
The fracture resulting from the static compression test is classified as a slip fracture due to the location of the crack at an angle of $45 \%$ for normal forces. This means that during compression, the sample was subjected to plastic deformation. It can be seen that the sides are deformed in characteristic barrel shape and cracked diagonally during destruction. Figure 12 presents the cross-section, created by the fracture of the sample, taken transversely to the sample axis along with an oblique photo of this cross-section with a visible slip direction.
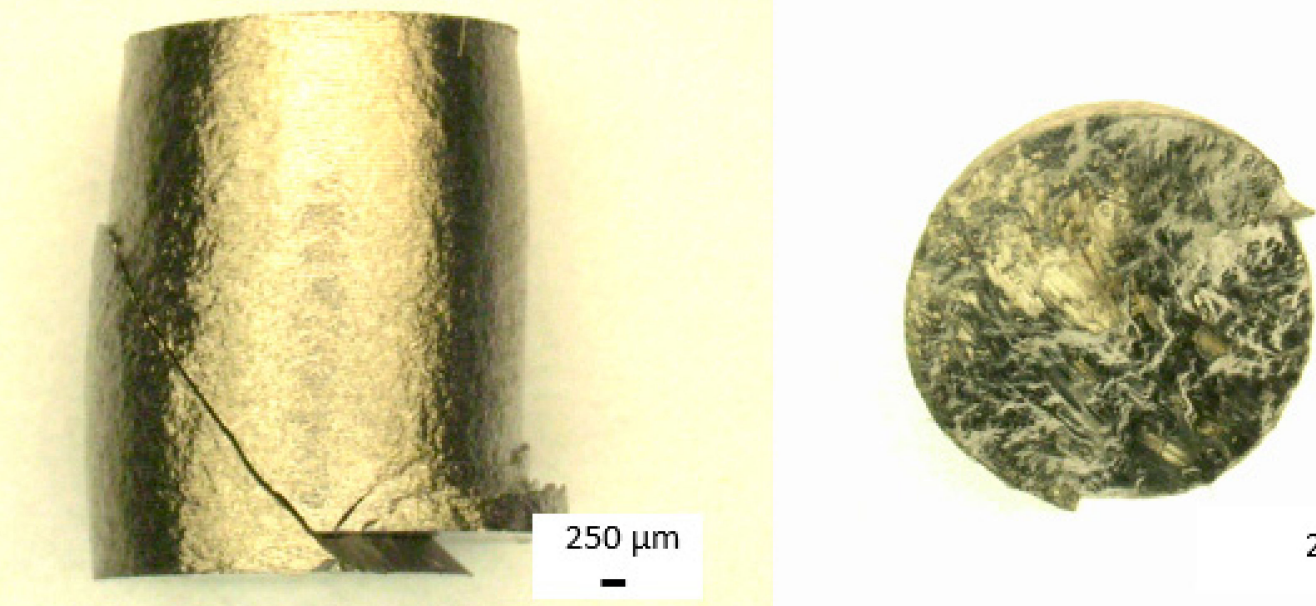

$250 \mu \mathrm{m}$

Figure 12. Light microscopy images of Ti-13Nb-13Zr samples after static compression test.

After three-point bending, it was observed that samples have a characteristic brittle fracture, i.e., they cracked without visible deformation. The characteristic appearance for this type of fracture is also visible-grainy and shiny (Figure 13). A crack appeared in the center of the sample between the lower loading rollers.

\subsection{Electrochemical Properties Analyses}

Potentiodynamic polarisation was used for corrosion resistance measuring. The parameters of the corrosion process from Tafel curves are presented in Table 5. An example curve is presented in Figure 14.

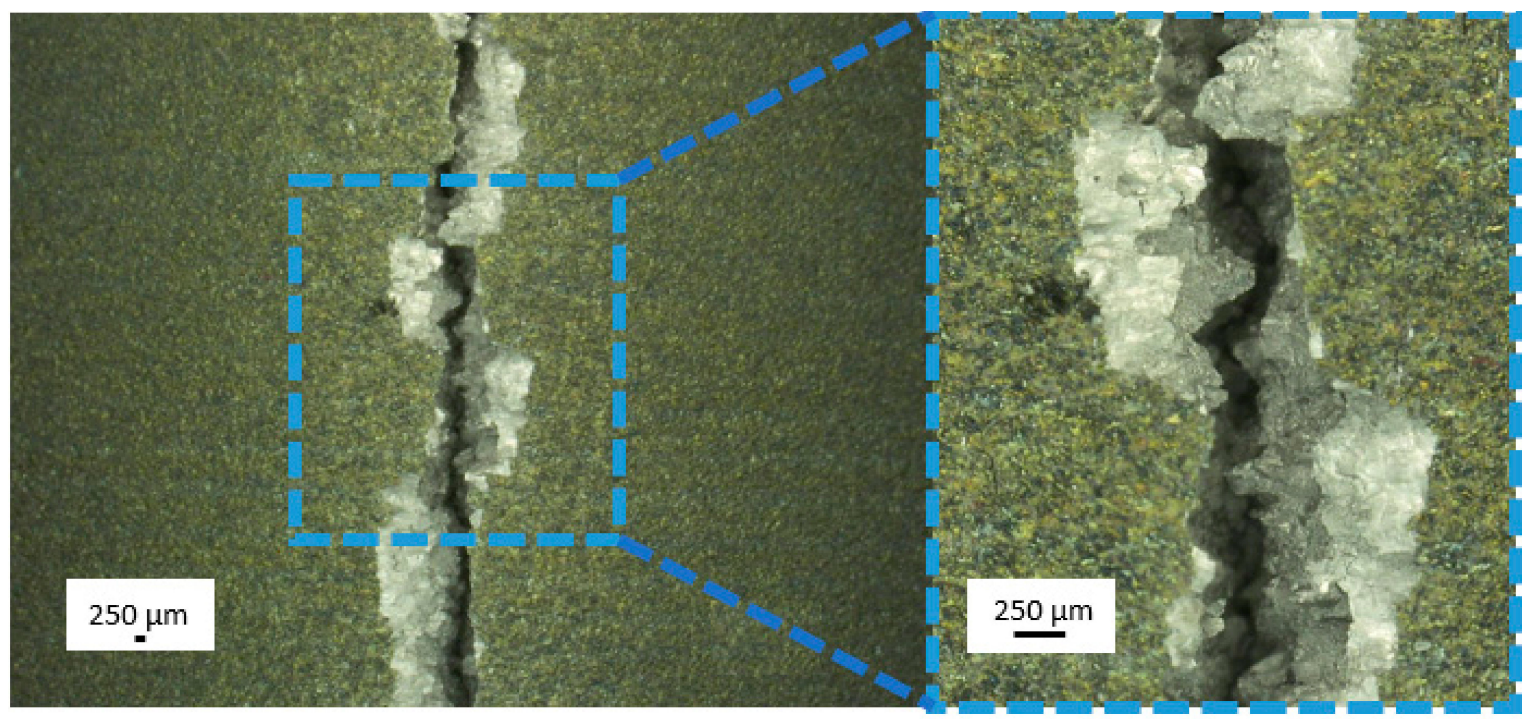

Figure 13. Light microscopy images of Ti-13Nb-13Zr samples after the three-point bending test. 
Table 5. Polarisation parameters and corrosion rates evaluated with the Tafel method ( $\mathrm{E}_{\mathrm{corr}}$-rest potential, $b_{a}$ and $b_{c}$ - anodic and cathodic Tafel slopes, $I_{\text {corr }}$-corrosion current density, $R_{\mathrm{p}}$ - polarisation resistance).

\begin{tabular}{cccccc}
\hline & $\begin{array}{c}\mathbf{E}_{\mathbf{c o r r}} \\
\mathbf{m V}\end{array}$ & $\begin{array}{c}\mathbf{b}_{\mathbf{a}} \\
\mathbf{m V ~ d e c} \mathbf{- 1}\end{array}$ & $\begin{array}{c}\mathbf{b}_{\mathbf{c}} \\
\mathbf{m ~ V ~ d e c} \mathbf{~ d e c r}\end{array}$ & $\begin{array}{c}\mathbf{I}_{\text {corr }} \\
\boldsymbol{\mu A} \cdot \mathbf{c m}^{-2}\end{array}$ & $\begin{array}{c}\mathbf{R}_{\mathbf{p}} \\
\mathbf{k} \Omega \cdot \mathbf{c m}^{\mathbf{2}}\end{array}$ \\
\hline mean & -366.83 & 208.33 & 191.64 & 0.091 & 523.97 \\
\hline SD & 42.67 & 46.06 & 16.43 & 0.033 & 170.97 \\
\hline
\end{tabular}

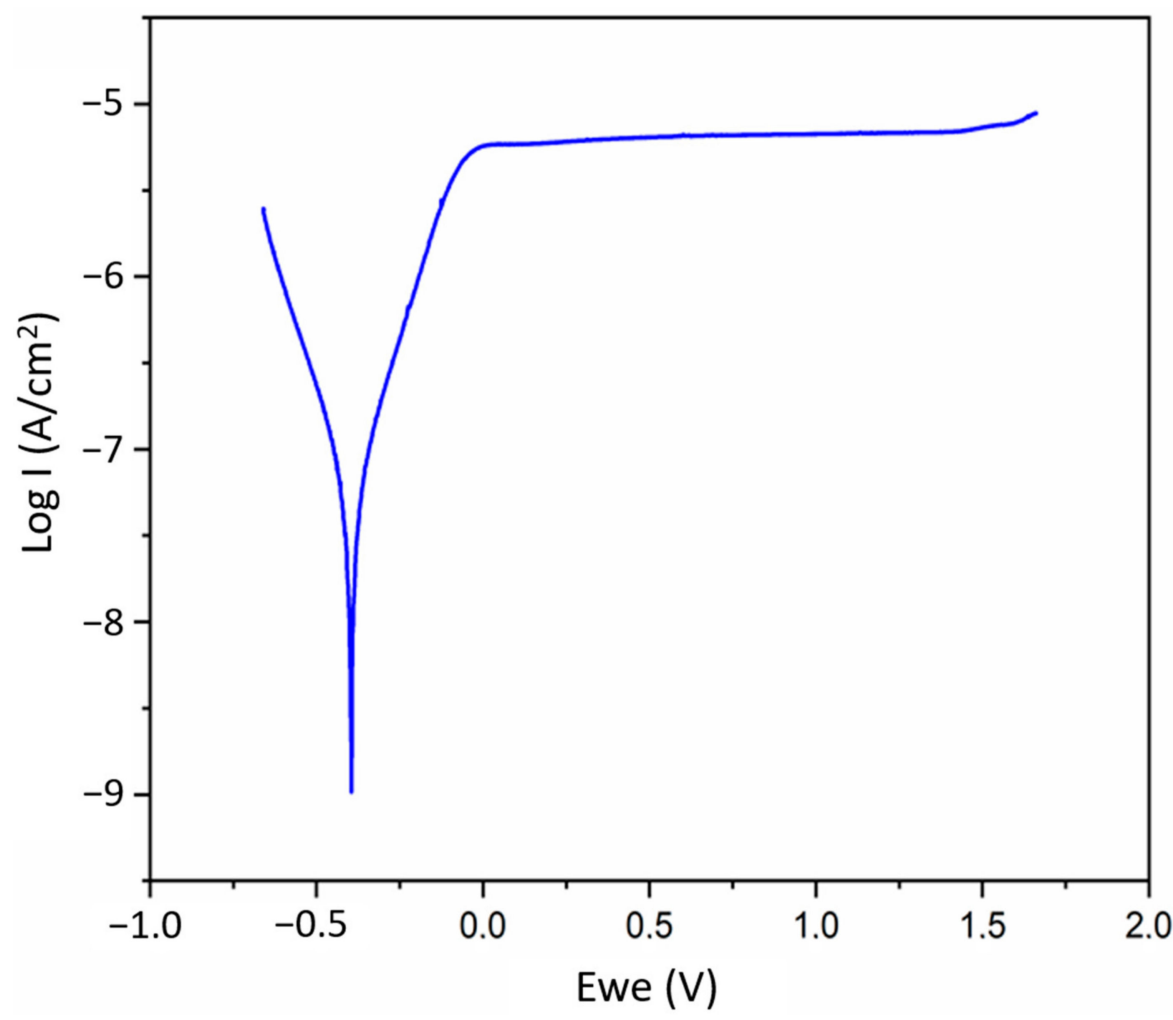

Figure 14. Potentiodynamic polarisation curve, recorded in Ringer's solution at room temperature.

As can be seen, the polarisation curve of the investigated alloy shows a broad passive area from 0 to $1.5 \mathrm{~V}$ when the current anodic density remained unchanged as the potential increased. This area indicates protective oxide film formation to prevent the continual metal from dissolving and thus inhibiting anodic process. For these samples, the anodic reaction was limited to the dynamic of the corrosion degradation - the mechanism of anodic protection. The results indicate that the passive film consists of a single layer and its resistance, $R_{p}$, was equivalent to $523.97 \pm 170.97 \mathrm{k} \Omega \mathrm{cm}^{2}$.

\subsection{Biological Properties Analyses}

Positive results were achieved in the verification of the biological properties. Taking into account the cellular behaviour of MC3T3 and NHDF cells on the Ti-13Nb-13Zr alloy, both cell lines show a high survival rate and lack of morphological changes: no intra-plasmatic granules, no cell lysis, and culture density is comparable to a negative culture. Detailed data from the MTT test for MC3T3 and NHDF are included in Tables 6 and 7, respectively.

For MC3T3 osteoblast cells, depending on the concentration of the extract, the cell survival rate is from $111.67 \pm 2.44 \%$ for $100 \%$ extract to $128.32 \pm 4.22 \%$ for $12.5 \%$ extract. A similar case can be observed for NHDF cells and their cell survival rate is from $111.75 \pm 3.04 \%$ for $100 \%$ extract to $129.05 \pm 9.08 \%$ for $12.5 \%$ extract. Tested Ti- $13 \mathrm{Nb}-13 \mathrm{Zr}$ alloy has not shown any cytotoxicity to MC3T3 and NHDF cell lines. 
Table 6. MTT test result for MC3T3 cells

\begin{tabular}{|c|c|c|c|c|c|c|}
\hline Test & Number of Samples & Concentration & Survival Rate (\%) & $\begin{array}{c}\text { Morphological Changes in Cell } \\
\text { Cultures }\end{array}$ & $\begin{array}{l}\text { Evaluation of Morphological } \\
\text { Changes in Cultures }\end{array}$ & Cytotoxicity \\
\hline Negative test & 5 & Untreated cells & 97.33 & $\begin{array}{l}\text { No intra-plasmatic granules, no cell } \\
\text { lysis was found. }\end{array}$ & 0 & none \\
\hline Positive test & 5 & $2 \mu \mathrm{g} / \mathrm{mL}$ & 50.91 & $\begin{array}{l}\text { Cell culture almost or completely } \\
\text { destroyed. }\end{array}$ & 4 & strong \\
\hline \multirow{4}{*}{$\mathrm{Ti}-13 \mathrm{Nb}-13 \mathrm{Zr}$} & 5 & $100 \%$ & $111.67 \pm 2.44$ & \multirow{4}{*}{$\begin{array}{l}\text { No intra-plasmatic granules, no cell } \\
\text { lysis was found. Culture density } \\
\text { comparable to negative culture. }\end{array}$} & 0 & none \\
\hline & 5 & $50 \%$ & $123.9 \pm 4.65$ & & 0 & none \\
\hline & 5 & $25 \%$ & $125.39 \pm 4.37$ & & 0 & none \\
\hline & 5 & $12.5 \%$ & $128.32 \pm 4.22$ & & 0 & none \\
\hline
\end{tabular}

Table 7. MTT test result for NHDF cells.

\begin{tabular}{|c|c|c|c|c|c|c|}
\hline Test & Number of Samples & Concentration & Survival Rate (\%) & $\begin{array}{c}\text { Morphological Changes in Cell } \\
\text { Cultures }\end{array}$ & $\begin{array}{l}\text { Evaluation of Morphological } \\
\text { Changes in Cultures }\end{array}$ & Cytotoxicity \\
\hline Negative test & 5 & Untreated cells & 98.17 & $\begin{array}{l}\text { No intra-plasmatic granules, No cell } \\
\text { lysis was found. }\end{array}$ & 0 & none \\
\hline Positive test & 5 & $2 \mu \mathrm{g} / \mathrm{mL}$ & 51.67 & $\begin{array}{l}\text { Cell culture almost or completely } \\
\text { destroyed. }\end{array}$ & 4 & strong \\
\hline \multirow{4}{*}{ Ti-13Nb-13Zr } & 5 & $100 \%$ & $111.75 \pm 3.04$ & \multirow{4}{*}{$\begin{array}{l}\text { No intra-plasmatic granules, no cell } \\
\text { lysis was found. Culture density } \\
\text { comparable to negative culture. }\end{array}$} & 0 & none \\
\hline & 5 & $50 \%$ & $116.5 \pm 1.58$ & & 0 & none \\
\hline & 5 & $25 \%$ & $125.31 \pm 4.65$ & & 0 & none \\
\hline & 5 & $12.5 \%$ & $129.05 \pm 9.08$ & & 0 & none \\
\hline
\end{tabular}




\section{Discussion}

Beta titanium alloys are promising materials for medical implants due to their alloying $\beta$-stabilising elements, which are also biocompatible and nontoxic. They exhibit a lower Young's modulus and better corrosion resistance than $\alpha$ and $\alpha+\beta$ alloys. The Ti- $13 \mathrm{Nb}-$ $13 \mathrm{Zr}$ alloy is a highly appreciated near $\beta$-type titanium alloy for biomedical applications since its development by Davidson et al. in the 1990s [43]. Titanium alloys exist in several crystallographic forms. At room temperature, titanium has an HCP (hexagonal closepacked) crystal structure called the $\alpha$ phase. This structure has the ability to transform at $883{ }^{\circ} \mathrm{C}$ to a BCC (body-centered cubic) crystal structure, referred to as the $\beta$ phase. In the case of the Ti-13Nb-13Zr alloy, its $\beta$-stabiliser is the niobium, which affects the microstructure and phase composition resulting in stability of the $\beta$ phase at a lower temperature [44]. Microscopic images obtained by scanning electron microscopy indicate the presence of the acicular phase $\alpha$ with martensitic origin (transformed $\beta$ ) in the $\beta$ phase matrix (Figure 1). Aijt et al. [17] and Khorasani et al. [45] indicate that the microstructure at room temperature contains $\alpha^{\prime}, \alpha$, and $\beta$ phases-implying that some of the $\beta$ phase transformed to $\alpha^{\prime}$, while the rest of the $\beta$ transformed into the equilibrium of $\alpha+\beta$ phase, which confirms the microstructure of the tested material in this research. It has been recognized by Liu et al. [10] that the metastable phase $\alpha^{\prime}$, formed martensitically by quenching, has the same crystal structure as the $\alpha$ phase. The $\alpha^{\prime}$ phase could dissolve the higher content of $\beta$ stabilisers than the stable $\alpha$ phase, and the more $\beta$ stabilisers, the lower the Young's modulus [10]. This statement confirms our XRD results and the presence of the phases mentioned above.

As a result of the intended application of the studied titanium alloy as a material for bone implants, one of the key factors to be considered is the Young's modulus, which should achieve values similar to bone parameters. Our studies show that $\mathrm{E}=84.1 \pm 1.8 \mathrm{GPa}$, which in turn is convergent with the results obtained by other scientists $[16,17,37]$ in the same heat treatment condition of Ti-13Nb-13Zr alloy (Table 8). The value of the Young's modulus of $\mathrm{Ti}-\mathrm{Nb}-\mathrm{Zr}$ alloys depends on the alloy's microstructure ( $\beta$ phase has a lower Young's modulus than the $\alpha$ phase), which in turn depends on the amount and type of alloying elements and the processing techniques. Thermal or mechanical processing causes changes in the microstructure of materials. In cold-worked materials, it results in deformation that makes the material stronger and harder, less ductile, and more chemically reactive. $\beta$-stabiliser elements ( $\mathrm{Nb}, \mathrm{Zr}, \mathrm{Hf}, \mathrm{Ta}, \mathrm{Mo}$, etc.) result in a lower elastic modulus [10], as the tested near-beta alloy, and another based on $\mathrm{Ti}-\mathrm{Zr}$ or Ti-Nb-Zr, which exhibit the Young's modulus $[11,16,46,47]$ lower by up to $30 \%$ compared with $\alpha$-alloys $[14,48]$.

Table 8. Comparison of the mechanical properties of Ti-13Nb-13Zr material with various heat treatment conditions.

\begin{tabular}{|c|c|c|c|c|}
\hline & UTS (MPa) & YS (MPa) & A (\%) & E (GPa) \\
\hline This research (annealed) & $733.9 \pm 7.5$ & $555.6 \pm 17.3$ & $19.6 \pm 1.6$ & $84.1 \pm 1.8$ \\
\hline Hardened $[17,43]$ & $798 \pm 17$ & $599 \pm 24$ & $20 \pm 3$ & $83 \pm 2$ \\
\hline WQ $[17,43]$ & $703-786$ & $433-554$ & $21-29$ & $64-77$ \\
\hline WQ + Aged. $[17,43]$ & $994 \pm 42$ & $864 \pm 43$ & $13 \pm 3$ & $81 \pm 4$ \\
\hline WQ + DH $[17,43]$ & $1034 \pm 5$ & $906 \pm 10$ & $11 \pm 1$ & $83 \pm 2$ \\
\hline$W Q+50-75 \% C W[17,43]$ & $1000-1055$ & $900-1000$ & $10-15$ & $44-51$ \\
\hline ST + WQ [16] & 860 & 640 & 15 & 60 \\
\hline $52 \%$ CW [16] & 1280 & 1270 & 12 & 52 \\
\hline
\end{tabular}

(WQ—water quenched; DH—diffusion hardened; CW—cold worked; ST—solution treated).

The characterisation of mechanical properties of the Ti-13Nb-13Zr alloy was performed with tensile, compression, and bending tests. Most scientists only carry out a tensile test to determine the mechanical properties, which does not show the alloy's mechanical properties under different load conditions. Therefore, we decided to extend the scope of 
mechanical tests with a static compression test and three-point bending, due to the fact that the parameters determined in these tests will allow for implementing their values into experimental models_-for example, for the finite element analysis. Mechanical properties of materials are crucial when designing load-bearing orthopaedic or dental implants. Implant failure is catastrophic because the fracture of any implant could be very dangerous for a patient. For example, during oral activities, implants are required to support axial loads around 120-200 N [49]. Observed fracture shows a mixed character. The area with features characteristic for the tough fracture is small. The occurrence of quasi-brittle fracture should be connected with the hexagonal $\alpha^{\prime}$ phase. It is assumed that increase of the ductility is caused by the transformation of the $\beta$ phase to $\alpha^{\prime}$ martensite [16].

Many scientists point to the superior corrosion properties of the $\mathrm{Ti}-13 \mathrm{Nb}-13 \mathrm{Zr}$ alloy [26,50]. The corrosion resistance of passive metals depends on the chemical composition of the oxide layer. This is mainly due to the solubility of oxides formed on the top layer- $\mathrm{Nb}$ and $\mathrm{Zr}$ oxides have lower solubility than $\mathrm{Al}$ and $\mathrm{V}$ oxides [51]. The XPS analysis [52] showed that the passive layer of Ti-13Nb-13Zr alloy was formed by a mixture of $\mathrm{TiO}_{2}, \mathrm{ZrO}_{2}$, and $\mathrm{Nb}_{2} \mathrm{O}_{5}$ oxides. Titanium oxide is well known as a typical nontoxic, highly photochemically active semiconductor, which provides self-disinfecting properties for biomaterial surfaces [53]. The confirmation of the presence of oxides of the alloy elements on the surface of the material tested in this study clearly indicates that this material is excellent for use in medical implants due to its high biocompatibility properties and the possibility of molecules adhering through the presence of $\mathrm{OH}$ groups [33,54]. In the case of corrosion, tests carried out on the Ti-13Nb-13Zr in Ringer's solution ( $\mathrm{pH} 7.3-7.4$ ) by other scientists [27] showed that corrosion current density at a temperature of $37^{\circ} \mathrm{C}$ was $0.12 \mu \mathrm{A} \mathrm{cm}^{-2}$. In the same temperature, [22] showed that $\mathrm{I}_{\text {corr }}$ is $1.77 \mu \mathrm{A} \mathrm{cm}^{-2}$. These values are very close to the data obtained in this study: $\mathrm{I}_{\mathrm{corr}}=0.091 \pm 0.033 \mu \mathrm{A} \mathrm{cm}{ }^{-2}$. Slight differences may be due to the different temperatures at which the experiments were conducted, but the results are nevertheless very consistent. The resistance of the passivating film formed on Ti-13Nb-13Zr alloys is higher than in case of CP Ti or Ti-6Al-4V alloy, which is indicative of the higher corrosion [23]. This resistance is attributed to the passive $\mathrm{TiO}_{2}$ layer, which inhibits the absorption of corrosive ions [55]. The passive layer alters the surface potential and limits the number of charge carriers in the metal-electrolyte interlayer, protecting the substrate from corrosion damage. All mentioned sources [14,22,27] indicate an occurrence of long passive potential, highlighting superior corrosion resistance. The results achieved in our MTT tests are coherent with similar tests reported in the literature, which also prove the absence of cytotoxic effects of titanium, as opposed to most other metallic elements [15]. These data confirm that the samples do not present any cytotoxic effect. Previous studies have also confirmed the high cytocompatibility of $\mathrm{Nb}, \mathrm{Ta}$, $\mathrm{Sn}$, and $\mathrm{Zr}$ as alloy elements [56], so the hypothesis is confirmed that the use of nontoxic elements results in the chemical composition of the alloy, which also has no cytotoxic properties. Further biological research using modified surfaces is necessary and will lead to a better understanding of biocompatibility of titanium alloys and other biological materials.

\section{Conclusions}

While designing and selecting biomaterials used in medical implants, it is crucial to make their mechanical, physical, chemical, and biological properties similar to those of living tissues. The comprehensive mechanical, physicochemical, and biological evaluation of Ti-13Nb-13Zr alloy was performed, and the results were compared with data from other scientists if those were available. The following main conclusions, supported by corresponsive data from other research, can be drawn:

1. The microstructure at room temperature was confirmed by SEM and XRD investigations and was found to contain $\alpha, \alpha^{\prime}$, and $\beta$ phases, implying that some of the $\beta$ phase transformed to $\alpha^{\prime}$. 
2. Mechanical properties obtained by the static tensile test are similar to the data found in the literature and conform to the requirements of ASTM F1713. For the annealed conditions: $\mathrm{E}=84.1 \pm 1.8 \mathrm{GPa}$, UTS $=733.9 \pm 7.5 \mathrm{MPa}, \mathrm{YS}=555.6 \pm 17.3 \mathrm{MPa}$, and $\mathrm{A}=19.6 \pm 1.6 \%$.

3. XPS results confirmed the dominant presence of $\mathrm{TiO}_{2}$ on the examined surface and showed the presence of hydroxyl groups on the surface. Moreover, other oxides are present $-\mathrm{Nb}_{2} \mathrm{O}_{5}$ and $\mathrm{Zr}_{2} \mathrm{O}$. The occurrence of oxides increases the biocompatibility of materials and hydroxide groups allow for covalent attachment of various molecules.

4. As shown by our Tafel-plot extrapolations, the Ti-13Nb-13Zr in the Ringer's solution spontaneously forms a passive layer, due to long passivation area on potentiodynamic polarisation curves.

5. The toxic effect was assessed by a cytotoxicity MTT test, which proved that the Ti-13Nb-13Zr alloy did not present cytotoxic effect in the in vitro examination both for MC3T3 and NHDF cells.

The most important and totally new discovery presented by this research is the results obtained by the extended scope of mechanical tests with the static compression and the three-point bending. These values, hard to find in the literature, were determined and the following results were obtained: UCS $=1378.9 \pm 55.8 \mathrm{MPa}, \mathrm{YSc}=757.3 \pm 34.9 \mathrm{MPa}$, and FS $=1708.2 \pm 43.9 \mathrm{MPa}$. Together with these tests, another important factor came to light: the observed fractures that exhibit the occurrence of quasi-brittle fracture associated with the presence of the hexagonal $\alpha^{\prime}$ phase. The determined parameters allow for implementing their values into experimental models, for example, for the finite element analysis. These key values for potential biomedical applications constitute to be essential when designing load-bearing orthopaedic or dental implants.

Author Contributions: Conceptualization, V.H. and P.S.-Z.; methodology, V.H.; software, V.H., D.P.; validation, V.H., M.R. and M.J.; formal analysis, V.H. and P.S.-Z.; investigation, V.H.; resources, V.H.; data curation, V.H., D.P.; writing-original draft preparation, V.H., P.S.-Z.; writing-review and editing, M.R. and B.D.; visualization, V.H.; supervision, B.D. and M.J.; project administration, V.H.; funding acquisition, V.H. All authors have read and agreed to the published version of the manuscript.

Funding: This research was funded by the National Centre of for Research and Development within the InterDOK POWR.03.02.00-00-I003/16 project concerning interdisciplinary doctoral theses.

Institutional Review Board Statement: Not applicable.

Informed Consent Statement: Not applicable.

Data Availability Statement: The data presented in this study are available on request from the corresponding author.

Conflicts of Interest: The authors declare no conflict of interest.

\section{References}

1. Bertol, L.S.; Júnior, W.K.; da Silva, F.P.; Aumund-Kopp, C. Medical design: Direct metal laser sintering of Ti-6Al-4V. Mater. Des. 2010, 31, 3982-3988. [CrossRef]

2. Spetzger, U.; Frasca, M.; König, S.A. Surgical planning, manufacturing and implantation of an individualized cervical fusion titanium cage using patient-specific data. Eur. Spine J. 2016, 25, 2239-2246. [CrossRef] [PubMed]

3. Wang, D.; Wang, Y.; Wu, S.; Lin, H.; Yang, Y.; Fan, S.; Gu, C.; Wang, J.; Song, C. Customized a Ti6Al4V bone plate for complex pelvic fracture by selective laser melting. Materials 2017, 10, 1. [CrossRef]

4. Fan, H.; Fu, J.; Li, X.; Pei, Y.; Li, X.; Pei, G.; Guo, Z. Implantation of customized 3-D printed titanium prosthesis in limb salvage surgery: A case series and review of the literature. World J. Surg. Oncol. 2015, 13, 1-10. [CrossRef] [PubMed]

5. Patel, N.; Gohil, P. A review on biomaterials: Scope, applications \& human anatomy significance. Int. J. Emerg. Technol. Adv. Eng. 2012, 2, 91-101.

6. Bai, L.; Gong, C.; Chen, X.; Sun, Y.; Zhang, J.; Cai, L.; Zhu, S.; Xie, S.Q. Additive manufacturing of customized metallic orthopedic implants: Materials, structures, and surface modifications. Metals 2019, 9, 1004. [CrossRef]

7. Park, Y.J.; Song, Y.H.; An, J.H.; Song, H.J.; Anusavice, K.J. Cytocompatibility of pure metals and experimental binary titanium alloys for implant materials. J. Dent. 2013, 41, 1251-1258. [CrossRef]

8. Li, Y.; Wong, C.; Xiong, J.; Hodgson, P.; Wen, C. Cytotoxicity of titanium and titanium alloying elements. J. Dent. Res. 2010, 89, 493-497. [CrossRef] 
9. Kolli, R.; Devaraj, A. A Review of Metastable Beta Titanium Alloys. Metals 2018, 8, 506. [CrossRef]

10. Liu, Q.; Meng, Q.; Guo, S.; Zhao, X. $\alpha^{\prime}$ Type Ti-Nb-Zr alloys with ultra-low Young's modulus and high strength. Prog. Nat. Sci. Mater. Int. 2013, 23, 562-565. [CrossRef]

11. Mohammed, M.T. Beta Titanium Alloys: The Lowest Elastic Modulus for Biomedical Applications: A Review Welding View project Powder Metallurgy Titanium Alloys View project Arshad Noor Siddiquee Jamia Millia Islamia. Int. J. Chem. Nucl. Metall. Mater. Eng. 2014, 8, 822-827.

12. Niinomi, M. Mechanical biocompatibilities of titanium alloys for biomedical applications. J. Mech. Behav. Biomed. Mater. 2008, 1, 30-42. [CrossRef] [PubMed]

13. Niinomi, M.; Liu, Y.; Nakai, M.; Liu, H.; Li, H. Biomedical titanium alloys with Young's moduli close to that of cortical bone. Regen. Biomater. 2016, 3, 173-185. [CrossRef] [PubMed]

14. Geetha, M.; Singh, A.K.; Asokamani, R.; Gogia, A.K. Ti based biomaterials, the ultimate choice for orthopaedic implants-A review. Prog. Mater. Sci. 2009, 54, 397-425. [CrossRef]

15. Donato, T.A.G.; de Almeida, L.H.; Nogueira, R.A.; Niemeyer, T.C.; Grandini, C.R.; Caram, R.; Schneider, S.G.; Santos, A.R. Cytotoxicity study of some Ti alloys used as biomaterial. Mater. Sci. Eng. C 2009, 29, 1365-1369. [CrossRef]

16. Schneider, S.G.; Nunes, C.A.; Rogero, S.O. Mechanical properties and cytotoxic evaluation of the Ti-3Nb-13Zr alloy. Biomecanica 2000, 8, 84-87. [CrossRef]

17. Mishra, A.K.; Davidson, J.A.; Poggie, R.A.; Kovacs, P.; Ted, J. Mechanical and tribological properties and biocompatibility of diffusion hardened Ti-13Nb-13Zr A new titanium alloy for surgical implants. ASTM Int. 1996, 96-113.

18. Black, J. Biological Performance of Materials_Fundamentals of Biocompability, 4th ed.; Taylor \& Francis Group, LCC: Abingdon, UK, 2006; ISBN 9781420057843.

19. Abdel-Hady Gepreel, M.; Niinomi, M. Biocompatibility of Ti-alloys for long-term implantation. J. Mech. Behav. Biomed. Mater. 2013, 20, 407-415. [CrossRef]

20. Ozaki, T.; Matsumoto, H.; Watanabe, S.; Hanada, S. Beta Ti Alloys with Low Young's Modulus. Mater. Trans. 2005, 45, 2776-2779. [CrossRef]

21. Chen, Q.; Thouas, G.A. Metallic implant biomaterials. Mater. Sci. Eng. R Rep. 2015, 87, 1-57. [CrossRef]

22. Saji, V.S.; Choe, H.C. Electrochemical corrosion behaviour of nanotubular Ti-13Nb-13Zr alloy in Ringer's solution. Corros. Sci. 2009, 51, 1658-1663. [CrossRef]

23. Cvijović-Alagić, I.; Cvijović, Z.; Mitrović, S.; Panić, V.; Rakin, M. Wear and corrosion behaviour of Ti-13Nb-13Zr and Ti-6Al-4V alloys in simulated physiological solution. Corros. Sci. 2011, 53, 796-808. [CrossRef]

24. Geetha, M.; Kamachi Mudali, U.; Gogia, A.K.; Asokamani, R.; Raj, B. Influence of microstructure and alloying elements on corrosion behavior of Ti-13Nb-13Zr alloy. Corros. Sci. 2004, 46, 877-892. [CrossRef]

25. Taekyung, L.; Eshaan, M.; Santhosh, R.; Geetha, M.; Kumar, S.A.; Soo, L.C. Tribological and corrosion behaviors of warm- and hot-rolled Ti-13Nb-13Zr alloys in simulated body fluid conditions. Int. J. Nanomed. 2015, 10, 207-212.

26. Niemeyer, T.C.; Grandini, C.R.; Pinto, L.M.C.; Angelo, A.C.D.; Schneider, S.G. Corrosion behavior of Ti-13Nb-13Zr alloy used as a biomaterial. J. Alloy Compd. 2009, 476, 172-175. [CrossRef]

27. Robin, A.; Carvalho, O.A.S.; Schneider, S.G.; Schneider, S.G. Corrosion behavior of Ti-xNb-13Zr alloys in Ringer's solution. Mater. Corros. 2008, 59, 929-933. [CrossRef]

28. Dinu, M.; Franchi, S.; Pruna, V.; Cotrut, C.M.; Secchi, V.; Santi, M.; Titorencu, I.; Battocchio, C.; Iucci, G.; Vladescu, A. Ti-Nb-Zr System and Its Surface Biofunctionalization for Biomedical Applications; Elsevier Inc.: Amsterdam, The Netherlands, 2018; ISBN 9780128124567.

29. Thomsen, P.; Johansson, C.B. A selection of oral implant materials based on experimental studies. In Bio Implant Interface Improving Biomaterials Tissue Reactions; CRC PRESS: Boca Raton, FL, USA, 2003; pp. 183-203. [CrossRef]

30. ASTM E8/E8M-16a. Standard Test Methods for Tension Testing of Metallic Materials; ASTM International: West Conshohocken, PA, USA, 2016.

31. ASTM E9-09. Standard Test Methods of Compression Testing of Metallic Materials at Room Temperature; ASTM International: West Conshohocken, PA, USA, 2009.

32. ASTM E290-14. Standard Test Methods for Bend Testing of Material for Ductility; ASTM International: West Conshohocken, PA, USA, 2014.

33. EN ISO 10993-5: 2012. Biological Evaluation of Medical Devices. Tests for In Vitro Cytotoxicity; ISO: Geneva, Switzerland, 2012.

34. EN ISO 10993-5: 2009. Biological Evaluation of Medical Devices. Tests for In Vitro Cytotoxicity; ISO: Geneva, Switzerland, 2009.

35. ASTM F1713-08 (2013). Standard Specification for Wrought Titanium-13Niobium-13Zirconium Alloy for Surgical Implant Applications (UNS R58130); ASTM International: West Conshohocken, PA, USA, 2013.

36. National Institute of Standards and Technology. NIST X-ray Photoelectron Spectroscopy Database; National Institute of Standards and Technology: Gaithersburg, MD, USA, 2000.

37. Biesinger, M.C.; Lau, L.W.M.; Gerson, A.R.; Smart, R.S.C. Resolving surface chemical states in XPS analysis of first row transition metals, oxides and hydroxides: Sc, Ti, V., Cu and Zn. Appl. Surf. Sci. 2010, 257, 887-898. [CrossRef]

38. Kasemo, B.; Lausmaa, J. Aspects of surface physics on titanium implants. Swed. Dent. J. Suppl. 1985, 28, 19-36.

39. Lausmaa, J. Surface spectroscopic characterization of titanium implant materials. J. Electron Spectros. Relat. Phenom. 1996, 81, 343-361. [CrossRef] 
40. Diebold, U.; Madey, T.E. TiO2 by XPS. Surf. Sci. Spectra 1996, 4, 227-231. [CrossRef]

41. Buabthong, P.; Stasiewicz, N.B.; Mitrovic, S.; Lewis, N.S. Vanadium, niobium and tantalum by XPS. Surf. Sci. Spectra 2017, 24, 024001. [CrossRef]

42. Barreca, D.; Battiston, G.A.; Gerbasi, R.; Tondello, E.; Zanella, P. Zirconium Dioxide Thin Films Characterized by XPS. Surf. Sci. Spectra 2000, 7, 303-309. [CrossRef]

43. Davidson, J.A.; Kovacs, P. Biocompatible Low Modulus Titanium Alloy for Medical Implants. U.S. Patent No. 5,169,597, 8 December 1992.

44. Ozaltin, K.; Panigrahi, A.; Chrominski, W.; Bulutsuz, A.G.; Kulczyk, M.; Zehetbauer, M.J.; Lewandowska, M. Microstructure and Texture Evolutions of Biomedical Ti-13Nb-13Zr Alloy Processed by Hydrostatic Extrusion. Metall. Mater. Trans. A Phys. Metall. Mater. Sci. 2017, 48, 5747-5755. [CrossRef]

45. Khorasani, A.M.; Goldberg, M.; Doeven, E.H.; Littlefair, G. Titanium in Biomedical Applications—Properties and Fabrication: A Review. J. Biomater. Tissue Eng. 2015, 5, 593-619. [CrossRef]

46. Laheurte, P.; Prima, F.; Eberhardt, A.; Gloriant, T.; Wary, M.; Patoor, E. Mechanical properties of low modulus $\beta$ titanium alloys designed from the electronic approach. J. Mech. Behav. Biomed. Mater. 2010, 3, 565-573. [CrossRef]

47. Terlinde, G.; Fischer, G.; Metallwerke, O.F. Beta Titanium Alloys. In Titanium and Titanium Alloys. Fundamentals and Applications; Leyens, Christoph, Peters, M., Eds.; Wiley-VCH: Weinheim, Germany, 2003; ISBN 3527305343.

48. Zhang, L.C.; Chen, L.Y. A Review on Biomedical Titanium Alloys: Recent Progress and Prospect. Adv. Eng. Mater. 2019, 21, 1-29. [CrossRef]

49. Gil, F.J.; La, P.; Rios, J. V Implant-Abutment connections: Influence of the design on the microgap and their fatigue and fracture behavior of dental implants. J. Mater. Sci. Mater. Med. 2014, 1825-1830. [CrossRef]

50. Lorenzetti, M.; Pellicer, E.; Sort, J.; Baró, M.D.; Kovač, J.; Novak, S.; Kobe, S. Improvement to the corrosion resistance of Ti-based implants using hydrothermally synthesized nanostructured anatase coatings. Materials 2014, 7, 180-194. [CrossRef]

51. Hammer, P. Are new TiNbZr alloys potential substitutes of the Ti6Al4V alloy for dental applications? Biomed. Mater. 2013, 8 . [CrossRef]

52. Stróż, A.; Łosiewicz, B.; Zubko, M.; Chmiela, B.; Balin, K.; Dercz, G.; Gawlikowski, M.; Goryczka, T. Production, structure and biocompatible properties of oxide nanotubes on Ti13Nb13Zr alloy for medical applications. Mater. Charact. 2017, 132, 363-372. [CrossRef]

53. Chouirfa, H.; Bouloussa, H.; Migonney, V.; Falentin-Daudré, C. Review of titanium surface modification techniques and coatings for antibacterial applications. Acta Biomater. 2019, 83, 37-54. [CrossRef]

54. Li, S.; Ni, J.; Liu, X.; Zhang, X.; Yin, S.; Rong, M.; Guo, Z.; Zhou, L. Surface characteristics and biocompatibility of sandblasted and acid-etched titanium surface modified by ultraviolet irradiation: An in vitro study. J. Biomed. Mater. Res. Part B Appl. Biomater. 2012, 100, 1587-1598. [CrossRef]

55. Barjaktarević, D.R.; Cvijović-Alagić, I.L.; Dimić, I.D.; Đokić, V.R.; Rakin, M.P. Anodization of Ti-based materials for biomedical applications: A review. Metall. Mater. Eng. 2016, 22, 129-144. [CrossRef]

56. Cremasco, A.; Messias, A.D.; Esposito, A.R.; Duek, E.A.D.R.; Caram, R. Effects of alloying elements on the cytotoxic response of titanium alloys. Mater. Sci. Eng. C 2011, 31, 833-839. [CrossRef] 